\title{
An empirical assessment of the Swedish Bullionist
}

\section{Controversy*}

\author{
Nils Herger ${ }^{\dagger}$
}

\begin{abstract}
In the eighteenth century, a fierce political debate broke out in Sweden about the causes of an extraordinary depreciation of the currency. More specifically, the deteriorating value of the Swedish currency was discretionarily blamed on monetary causes, e.g. the overissuing of banknotes, or nonmonetary causes, such as balance-of-payments deficits. This paper provides a comprehensive empirical assessment of this so-called "Swedish Bullionist Controversy". The results of vector autoregressions suggest that increasing amounts of paper money did give rise to inflation and a depreciation of the exchange rate. Conversely, nonmonetary factors were probably less important for these developments.
\end{abstract}

JEL classification: B12, B17, E42, F31, N13

Keywords: bullionism, floating exchange rate, inconvertible banknotes, paper money, Sweden

\footnotetext{
*This paper has benefited from insightful comments by two anonymous referees. The usual disclaimer applies.

†Study Center Gerzensee, Dorfstrasse 2, P.O. Box 21, 3115 Gerzensee, Switzerland, E-mail: nils.herger@szgerzensee.ch, Tel: +41 (0)31780 3114.

This article has been accepted for publication and undergone full peer review but has not been through the copyediting, typesetting, pagination and proofreading process, which may lead to differences between this version and the Version of Record. Please cite this article as doi:
} 


\section{Introduction}

"Bullionism" commonly refers to an economic point of view in a famous controversy about the effects of inconvertible paper money in Britain during the so-called "Bank Restriction Period" (1797 - 1821). In particular, after the Bank of England had suspended the goldconvertibility of its banknotes in 1797 to deal with the major financial disturbances from the Napoleonic wars, a fierce debate broke out between a bullionist (or anti-restrictionist) and an anti-bullionist camp as to whether inconvertible paper money was responsible for the subsequent price instability for goods and foreign currency (see Viner, 1937, ch.3; ch.4). ${ }^{1}$ According to the bullionists, the severing of the specie-link of Bank of England notes had paved the way towards overissuing which, in turn, resulted in a deterioration of the value of sterling (see Viner, 1937, pp.124ff.). Conversely, to explain price and exchange-rate changes, the anti-bullionists emphasised the role of nonmonetary factors such as balance-ofpayments deficits caused by large food imports after bad harvests, or by extraordinary capital outflows to support allied powers on the European continent. Meanwhile, the upsurge of banknotes in circulation was interpreted as a symptom of these developments (Viner, 1937, pp.136ff.). This controversy matters even today, since it anticipated important questions in monetary economics about the impact of fiat money on prices and the determinants of floating exchange rates. Above all, in rudimentary form, the monetary as well as the balance-of-payments approach to determine the exchange rate are already encapsulated in, respectively, the bullionist and the anti-bullionist position. Furthermore, to make their case, later monetary debates - above all between the Keynesians and Monetarists - often revisited the experiences of Britain around 1800.

Owing to the lack of sophisticated econometric tools, contemporaneous empirical assessments of the Bullionist Controversy did not go beyond subjective interpretations of data figures and tables. However, even the later empirical work is arguably prone to finding spurious correlations between times series of banknotes in circulation, exchange rates, the price level, or real output (see Officer, 2008, p.7). It was not until Officer (2000) when multivariate timeseries techniques, in form of vector autoregressions (VARs), were introduced to account for the potential presence of unit roots, cointegrating relationships, and to deal with the

\footnotetext{
${ }^{1}$ In a narrow sense, the controversy dealt with the question as to whether excessive amounts of banknotes had been issued and, hence, the paper pound had been depreciated relative to the benchmark of a goldbacked currency. However, insofar as a depreciation manifests itself in a premium of gold (e.g. the external currency value) over inconvertible banknotes, the answer to this question is closely intertwined with the appropriate level of the exchange rate and prices in general (Eagly, 1963, p.627; Myhrman, 1976, p.171).
} 
thorny identification issues when uncovering the structural interrelationships arising from inconvertible paper money during the Bank Restriction Period. Nevertheless, Hendrickson (2018a, pp.227ff.) has recently argued that even this latest empirical work is flawed, by e.g. confounding Granger causality with economic causality to determine the VAR structure. ${ }^{2}$ Given these methodological shortcomings, it is perhaps not surprising that the empirical literature has hitherto been inconclusive in the sense of reporting evidence in favour of the anti-bullionist (e.g. Nachane and Hatekar, 1995; Officer, 2000), but also the bullionist position (Hendrickson, 2018a).

This paper focuses on the "Swedish Bullionist Controversy", which also dealt with the interrelationship between inconvertible paper money and a deteriorating currency value, but predated its British namesake by about 50 years (see Myhrman, 1976). In particular, after an inconvertible paper currency had replaced a metallic system in the 1740s, the amount of Swedish banknotes grew rapidly resulting in a currency system consisting mainly of fiat money, which was extraordinary in those days. Throughout the $1750 \mathrm{~s}$, the corresponding expansionary money and credit policy was accompanied by a marked increase in the average price level as well as an exceptionally large depreciation of the Swedish currency relative to foreign currencies maintaining the convertibility into silver or gold. Similar to the later British case, an intense debate broke out between two political factions as to whether the increasing amount of inconvertible banknotes was the cause, or merely a consequence, of these economic phenomena.

Against this background, this paper endeavours to conduct the first, comprehensive empirical assessment of the Swedish Bullionist Controversy. ${ }^{3}$ Based on historical data including prices, exchange rates, government debt, as well as the amount of issued paper money, VARs are employed to uncover the causes of the depreciation of the Swedish currency. In contrast to Officer (2000), the structural identification will explicitly allow for the different theories of the exchange rate invoked by the bullionists and the anti-bullionists. In any case, the results lend support to the monetary view that an overissuing of inconvertible banknotes did give rise to an upsurge of inflation and a marked depreciation of the currency. Conversely, the

\footnotetext{
${ }^{2}$ For the case of the Keynesians vs. Monetarists debate, the point that the temporal correlations inherent in Granger causality tests are not necessarily informative about the structural connections between variables has long been made by Tobin (1970). For a more general discussion on the limited capabilities of Grangercausality tests to uncover structural relationships, see Geweke (1984).

${ }^{3}$ Some rudimentary results have been published in previous work. In particular, Eagly (1971), Myhrman (1976), and Bernholz (2003, p.41ff.) report descriptive figures, whereas Jonung (1976) calculates correlations showing a co-movement between banknotes, prices, and exchange rates for mid-eighteenth century Sweden.
} 
view that a deteriorating balance of payments was to blame for the loss of purchasing power of the Swedish currency finds only partial support.

The paper is organised as follows. The next section provides a synoptic overview of the Swedish Bullionist Controversy. Section 3 introduces the econometric strategy. Section 4 presents the data. Section 5 reports the empirical results. Section 6 summarises and concludes.

\section{Historical background on the Swedish Bullionist Con- troversy}

\subsection{Copper mercantilism, trimetallism, and paper money in seven- teenth and eighteenth-century Sweden}

Between 1624 and 1776 , Sweden ${ }^{4}$ had a rather peculiar currency system, which was to a large extent based on copper, whereas elsewhere in Europe, silver and gold were the dominant monetary metals. ${ }^{5}$ This copper standard was an artefact of the rich deposits at the Great Copper Mountain near Falun, which gave Sweden a near-monopoly in European copper mining during the seventeenth and eighteenth century (see Heckscher, 1954, pp.84-88; Edvinsson, 2012a, p.422). With the copper industry being firmly under government control, the corresponding exports provided a key source of foreign revenue and were of particular importance for war finance. Ideologically, the establishment of a copper standard was heavily influenced by mercantilistic theories, according to which a domestic demand for copper coins was needed to increase the profit from the Falun mine and alleviate a perceived shortage of domestic money (see Heckscher, 1954, pp.88ff.; Edvinsson, 2012b, p.304). Taken together, these goals reflect salient mercantilistic dogmas that an abundant access to precious metals represents a key determinant for the wealth and power of the nation (see Heckscher, 1955, part 4).

Throughout the seventeenth and eighteenth centuries, the Swedish currency system was not entirely based on copper (see Edvinsson, 2010, pp.43-44). Rather, several silver-based coins

\footnotetext{
${ }^{4}$ At the time, the Kingdom of Sweden not only covered the current Swedish territory, but also Finland, and until after the Great Northern War (1700-1721) even parts of Pomerania and the Baltic States. During the remainder to the text, "Sweden" refers to territory covered during the seventeenth and eighteenth century. For this, see also Edvinsson (2010, pp.26-27).

${ }^{5}$ A historical overview of Sweden's monetary standards can be found in Edvinsson (2010). Heckscher (1954, pp.88ff; pp.197ff.) provides a corresponding overview of monetary history.
} 
continued to circulate alongside their copper-based varieties (see also Edvinsson, 2012a). Inevitably, this gave rise to a fragmented currency system with multiple means of payment, various units of account, and numerous exchange rates with respect to foreign currency, but also among the different types of Swedish coins in circulation. As such, it was not exceptional to have a multi-currency standard at the time- bimetallic systems based on gold and silver-backed currency were indeed quite common in Europe until the nineteenth century (see e.g. Redish, 2000). However, the monetary situation in Sweden after 1624 was unique by being based on a trimetallic standard with gold and silver as well as copper as monetary metal (Edvinsson, 2012a). Furthermore, in contrast to other examples in Europe, copper coins circulated at their intrinsic value to effectively boost the corresponding demand (see Edvinsson, 2010, p.39).

The copper standard had unintended consequences. Since copper is heavy compared with its value, the corresponding coins were ill-suited for large payments (Heckscher, 1954, pp.8990). ${ }^{6}$ During the seventeenth century, so-called "copper notes", e.g. written claims on a specific amount of copper, appeared to avoid the inconvenience of carrying large amounts of monetary metal (Heckscher, 1954, p.91). By accident rather than by design, these copper notes provided the nucleus of paper money and, subsequently, also paved the way to an early experiment with a fiat-currency system (see e.g. Kindleberger, 1984, p.50; Heckscher, 1954, pp.88-92). More specifically, Swedish paper money originated in a series of banking schemes, including the short-lived Stockholm Banco, which issued some of the first banknotes in Europe in the early 1660s. However, due to overissuing and a subsequent bank run, the Stockholm Banco quickly collapsed and was replaced by the Riksens Ständers Bank, which was a financial scheme backed by the "estates of the realm" (Swedish: Ständers), e.g. the noble, clerical, burghes, and land-owning peasant classes represented at the time in Swedish parliament, the Riksdag. ${ }^{7}$ Initially, the purpose of this officially supported banking scheme was to collect funds for the government; above all to finance wars against rival powers such as Denmark or Russia, but also to foster economic development by granting subsidised loans to the manufacturing sector (Eagly, 1971, pp.13ff.). However, after the year 1701, the Riksens Ständers Bank also began to issue its own paper money in form of so-called "transfer notes", which were originally fully convertible into monetary metal.

\footnotetext{
${ }^{6}$ The fact that copper was sometimes minted into plates weighting several kilos, rather than coins, underscores the severity of the problem. A picture of a copper plate can be found in Edvinsson (2010, p.40).

${ }^{7}$ In 1866, the Riksens Ständers Bank was renamed the Swedish Riksbank, which prides itself to be the oldest central bank in the world (see e.g. Kindleberger, 1984, p.50).
} 
Reflecting the bad experiences with the Stockholm Banco, as illustrated by the top panel of Figure 1, only small amounts of banknotes circulated before 1710. Thereafter, the situation changed and by the mid-eighteenth century, paper money was a dominant feature of Sweden's monetary system (Heckscher, 1954, p.197; Eagly, 1963, p.627). This transition was largely driven by the financial burden from a number of major wars inflicted on the Riksens Ständers Bank. In particular, Sweden was virtually bankrupted by its participation in the Great Northern War (1700-1721), which manifested itself in a sharp increase in public debt when substantial parts of the accumulated financial obligations at the Riksens Ständers Bank were transferred to the government in 1719 (see Roberts, 1986, pp.15ff.; Fregert and Gustafsson, 2014, pp.204ff.). Furthermore, between 1716 and 1719, the convertibility of paper money into copper had even to be suspended. A similar situation arose after Sweden's war with Russia (1741-1743) ${ }^{8}$, which was again partly financed through borrowing from the Riksens Ständers Bank and, in 1745, lead to a suspension of convertibility that lasted for more than 30 years (Jonung, 1976, p.42). It was during this period of inconvertible paper money when the Swedish Bullionist Controversy took place.

\subsection{Political controversy between the Hats and the Caps}

Severing the link to copper in 1745 removed the built-in safeguard of a metal-based currency system against overissuing money. In this regard, the impact of the Seven Years' War after 1757 was more dramatic than anything before (Eagly, 1969, p.750). As shown by Figure 1, the amount of banknotes in circulation more than trebled from 41 in 1755 to 135 million copper daler in 1762 . These developments were accompanied by pervasive levels of inflation and, moreover, an unprecedented depreciation of the exchange rate (Eagly, 1969, pp.743747). Inevitably, questions were raised as regards the causes of these extraordinary economic phenomena, which did not occur elsewhere in Europe, where metal-based currency systems remained intact. It is important to realise that the corresponding debates fell into the Age of Liberty (1720 - 1772), which was an enlightened era of Swedish history characterised by a climate of intellectual freedom with a system of government, where the Riksdag, rather than the monarchy, was at the centre of political power (Roberts, 1986). Although only a rudimentary form of democratic rule - with voting rights being restricted to the estates of the realm - there were already two opposing factions, called the "Hat party" and the

\footnotetext{
${ }^{8}$ Heckscher (1954, p.197) refers to this as the "Finnish war".
} 
Figure 1: Monetary and fiscal developments in the Kingdom of Sweden (1688 - 1776)
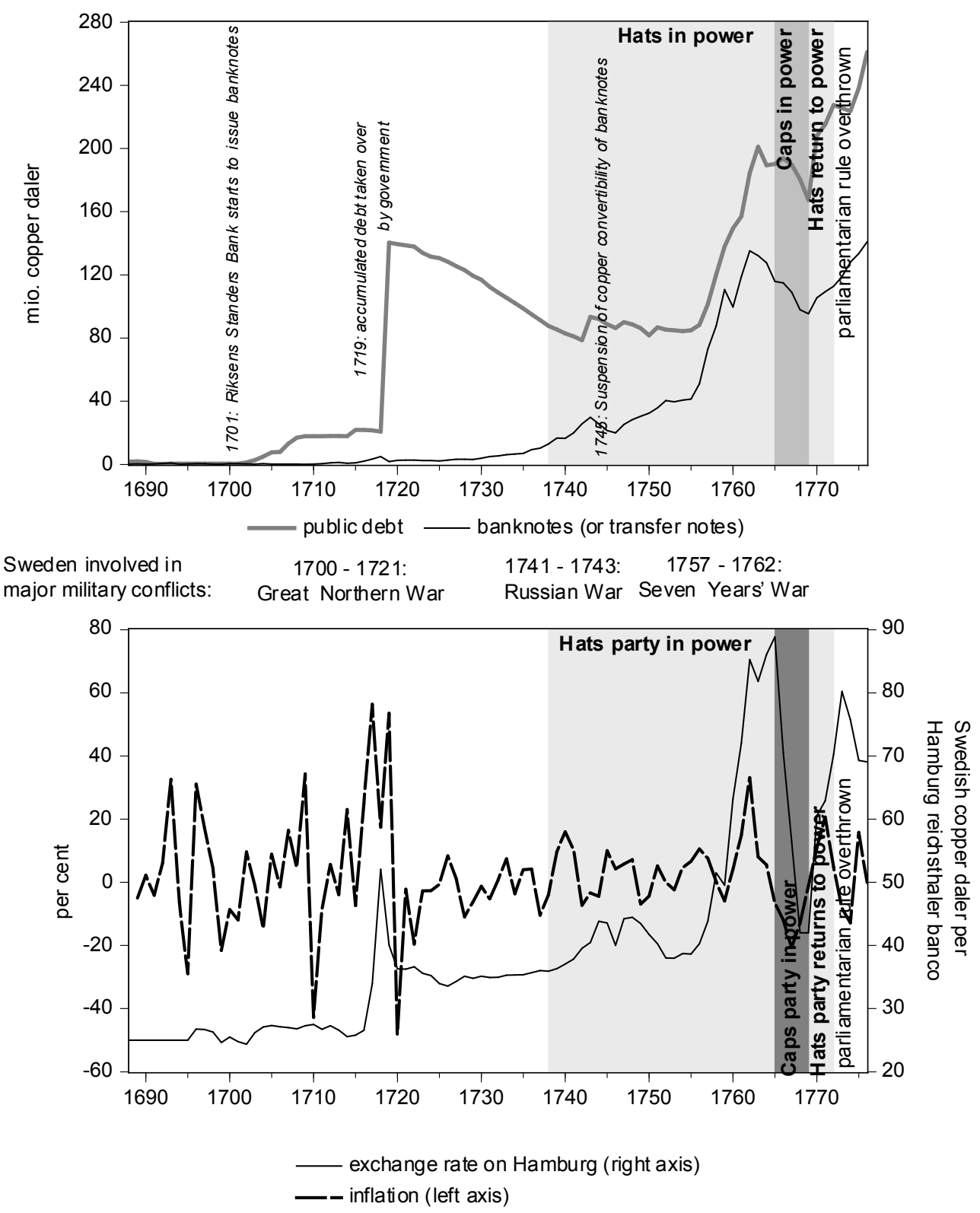

"Cap party", competing for political power. ${ }^{9}$ The Hats were the ruling party between 1739 and 1765 and, following the economic orthodoxy at the time, pursued a mercantilisminspired growth policy (see Eagly, 1971, pp.13ff.). The corresponding measures drew heavily on the Riksens Ständers Bank, which provided the financial vehicle to channel subsidised

\footnotetext{
${ }^{9}$ The Hats received their name from the tricorne hat, which was a fashion item across eighteenth-century Europe. The origin of the Caps' name is less flattering in the sense of referring to the nightcap, which was chosen by the establishment as a symbol to ridicule the opposition as an inherently inactive political group (see Roberts, 1986, p.114).
} 
loans to the domestic manufacturing sector (especially the textile and iron industry) and finance infrastructure projects such as roads and canals. Dismissing the inflationary bias of such a policy of cheap money, similar to the anti-bullionists in Britain, the Hats were convinced that external forces resulting in balance-of-payments deficits were to blame for the ongoing depreciation of the Swedish currency (see Myhrman, 1976, pp.174ff.; Eagly, 1969, pp.747ff.). The Caps, in their role of opposition party, disagreed with this view and blamed the loss of domestic and international purchasing power of Swedish money on homegrown problems, above all the overissuing of banknotes. Hence, in many regards, the Caps were the Swedish bullionists (Myhrman, 1976, p.175; Eagly, 1971, p.19). Rather than continuing with the expansion of money and credit, they argued that stable conditions could only be restored by bringing back the amount of paper money to levels before 1745 (see Eagly, 1969, pp.751ff.). Arguably, the proposition of a deflationary policy was mainly rooted in the desire to retaliate against the beneficiaries of the mercantilistic policies pursued by the Hatcontrolled government, rather than to implement a coherent economy programme (Eagly, 1971, pp.18ff.). However, with the dramatic deterioration of monetary stability during the Seven Years' War, price and exchange-rate increases reached intolerable levels and the debate tipped into the favour of the Caps, who managed to win a majority in the Riksdag in the year 1765 , and immediately began to implement their deflationary policies. Unsurprisingly, the declining price level and the appreciation of the Swedish currency led to an economic recession with falling exports, an upsurge in unemployment, and a collapse in real wages (Heckscher, 1954, p.198; Eagly, 1969, p.747). These adverse economic developments quickly reversed the political fortunes and the Hats returned to power as soon as 1769. The old monetary policies were resumed by depreciating the Swedish currency by around 50 per cent. The Age of Liberty came to an end in 1772 , when the monarchy managed to overthrow parliamentarian rule by a coup d'état (Roberts, 1986, pp.176ff.). Finally, in 1776, a currency reform introduced the "riksdaler", whose value was based on silver and, hence, ended the alliance between the Swedish currency and copper (Heckscher, 1954, pp.198-199).

\subsection{Academic legacy: Pehr Niclas Christiernin's voice of reason}

In terms of political economics, the Swedish Bullionist Controversy reflected a conflict between the vested interests of "commercial capitalists whose wealth was derived from foreign trade", who were aligned with the Hats, and "small industrialists, small merchants, and importers", who were by and large represented by the Caps (Eagly, 1971, p.18). Hence, finding 
the causes of the unstable currency value became a struggle for interpretative supremacy on the economic issue of the day. It is therefore not surprising that monetary issues were widely debated in Sweden during the 1750s and 1760s (Heckscher, 1954, pp.199ff.).

Although the Swedish Bullionist Controversy was driven by a political argument about the causes of the high price of foreign currency, it also left some remarkable academic contributions to international monetary economics. In particular, Pehr Niclas Christiernin (1725-1799), who spent his entire academic career at Scandinavia's oldest University in Uppsala, anticipated many insights of later macroeconomic models with fiat money and floating exchange rates (see Niehans, 1990, pp.56ff.). However, even among economists, Christiernin's name is barely known. His main contribution, which was published in 1761 under the Swedish title "Utdrag af Föreläsningar angående den Svea Rike upstigne WexelCoursen", was only made available to a broader readership through the partial translation by Robert V. Eagly (1971). However, P.N. Christiernin's "Lectures on the High Price of Foreign Exchange in Sweden" represent, arguably, the first clear analysis of the interrelationships between money, prices, exchange rates, and employment under a fiat-money system (at the time inconvertible banknotes) with floating exchange rates (see Niehans, 1990, pp.56-59; Eagly, 1963, pp.626ff.).

Despite lacking the formal rigour of modern monetary theories, Christiernin's writings are remarkably clear and concur with many views found in current textbooks on international monetary economics. Hence, it is worthwhile spelling out his thoughts about the state of the Swedish economy around the year 1760 in a couple of sentences (in the following, page numbers refer to Eagly's (1971) translation): Although P.N. Christiernin recognised that external factors resulting in balance-of-payments deficits can reduce the external value of a currency (pp.57ff.), he argued that under a metal-based currency system, these effects are constrained by the costs and risks of dispatching monetary metals (pp.61ff.). ${ }^{10}$ Since the marked increase in the price for foreign exchange around 1760 was a uniquely Swedish phenomenon, it should hence be attributed to specific, domestic circumstances (p.62). Excluding other possible causes such as the hoarding of coins (pp.62-63), a collusion between foreign-exchange traders (p.63), a balance-of-payments deficit (pp.63-64), or the provision of cheap loans to exporters (p.64-65), the excessive issuing of banknotes is left as the only plausible explanation (pp.66.ff.). Of course, by attributing the sharp nominal depreciation of the

\footnotetext{
${ }^{10}$ This insight coincides with the price-specie-flow mechanism developed by David Hume. Christiernien seems to have been familiar with Humes' work (see. Eagly, 1963, p.627).
} 
Swedish currency to monetary factors (p.29), Christiernin sided with the Caps. However, he did not agree with their economic therapy. In particular, he correctly foresaw that bringing back the amount of paper money to levels before 1745 would create a deflation and, due to price and wage rigidities, harm the economy. In his words: "The exchange rate cannot be reduced without economic disruptions" (p.89). It is even considered that the effect of contractionary monetary policies are particularly severe since "it is easy for prices to adjust upward when the money supply increases, but to get prices to fall has always been more difficult. No one reduces the price of his commodities or his labour until the lack of sales necessitates him to do so" (p.90; see also Myhrman, 1976, p.176). ${ }^{11}$ In particular, deflation and an appreciating exchange rate could increase the real debt burden (p.91), depress consumption (p.93), and give rise to high unemployment (p.95). To avoid a recession, rather than reappreciating the currency through a monetary contraction, Christiernien proposed to stabilise the exchange rate by providing the money supply to support the current level of economic transactions at the current level of prices and output (p.28).

\section{Methodology and structural identification of the bul- lionist controversy}

The complex interactions between monetary and nonmonetary variables lay at the heart of bullionist controversies. However, to resolve the thorny statistical issues of cause and effect between macroeconomic time series that are potentially highly interrelated among themselves, or endogenous, econometric methods such as structural vector autoregressions (VARs) are warranted that have only been developed during the last couple of decades. In particular, VARs have become a standard tool in monetary economics to uncover the dynamic effect of structural shocks, such as an unexpected upsurge in the amount of paper money, upon other variables. ${ }^{12}$

It is well known that VARs are overparameterised, e.g. the coefficient estimates, and the corresponding standard deviations, do not uniquely identify the structural relationship between the underlying variables. Thereto, identifying assumptions, which typically draw on

\footnotetext{
${ }^{11}$ Although downward price and wage inflexibility are today the hallmark of "Keynesian economics" (Eagly, 1963 , p.629), this quote is a testimony to the often ignored fact that classical economists had commonly attributed high levels of unemployment to wage and price rigidities (Niehans, 1990, pp.54, 59, 103).

${ }^{12}$ For an introductory textbook discussion on VARs, see Enders (2014, ch.5-6). For a discussion at the advanced level, see Lütkepohl (2010).
} 
theoretical considerations, are warranted. For example, to empirically assess the British Bullionist Controversy, the VAR analysis in Officer (2000) employs a causal ordering between the variables (encapsulated in a so-called "Cholesky ordering"). However, because the identifying assumptions of Officer (2000) have recently been questioned by Hendrickson (2018a), it is worthwhile to carefully develop the arguments supporting the current identification strategy.

Similar to Officer (2000), the identification of the VAR reflecting the Swedish Bullionist Controversy will be achieved via a theoretically informed Cholesky ordering. To this end, it is perhaps important to recall that the bullionists and anti-bullionists had fundamentally opposing views, or theories, about the role of note issuing for the development of the exchange rate and other economic variables. For the Swedish case, Kindleberger (1984, p.132) has nicely summarised how this maps, in turn, into different chains of causation:

\footnotetext{
"Like the bullionists in England later, the Caps contented that depreciation of the exchange rate was due to expansion of the money supply. In rebuttal, the Hats insisted that depreciation had started with the balance of payments; causation had run from balance of payments to depreciation to raising prices, not from money supply to rising prices to balance of payments and depreciation."
}

Insofar as the participants of Swedish Bullionist Controversy could not resort to modernday monetary models to present their arguments, some interpretative vagueness remains as regards the exact theoretical links the Caps and the Hats had in mind. Nevertheless, from the contemporaneous documents, it is probably safe to say that the Hats highlighted the effects of nonmonetary factors to explain increases in the exchange rate, denoted by $S$, and inflation, denoted by $\pi$. In particular, issues with the balance of payments could arise due to the need for state-sponsored economic development and of war finance, which would increase public debt $B$, or a poor quality of the harvest, denoted by $H Q$. The increase in the amount of banknotes, denoted here by $N$, was thought to be a mere consequence of these development. Taken together, and denoting a theoretical causality between economic variables by $\rightarrow$, the Hats' chain of causation looks probably as follows (compare Officer, 2008, p.5),

$$
H Q \rightarrow B \rightarrow S \rightarrow \pi \rightarrow N
$$


Of note, the connection between the exchange rate and inflation occurs via changes in import prices, which are here, as in Officer (2000, p.201), not separately measured. Moreover, in the British debate, the causality between inflation and the amount of banknotes in circulation was theoretically based on the real-bills doctrine, according to which it is impossible to overissue paper money, as long as it is used to pay for real goods and physical investment projects. Even if money would be issued for other, purely financial, purposes, this would be without consequences since it was thought that inflation would induce the public to hand back excessively issued amounts of paper money and, hence, automatically stabilise the price level (see Officer, 2000, p.200). Therefore, the causal link runs arguably from inflation to the amount of banknotes in circulation.

Conversely, the Caps advocated a chain of causation running from monetary variables such as the amount of inconvertible banknotes, to prices, and the exchange rate. ${ }^{13}$ Hence, similar to Officer $(2008$, p.3), the following connection arises,

$$
N \rightarrow \pi \rightarrow S
$$

Of note, this chain of causation embodies fragments of the quantity theory and purchasing power parity. ${ }^{14}$

Finally, by attributing the depreciation of the Swedish currency to monetary factors, P.N Christiernin sided with the Caps. However, he also allowed for short-term real economic effects of nominal price changes. In particular, introducing the possibility of having a deflationinduced recession, which is here represented by changes in real wages, his chain of causation would be given by

\footnotetext{
${ }^{13}$ For the British Bullionist Controversy, Officer (2008) also considers the price of gold, which was ignored in the Swedish debate, and would, perhaps, just be an alternative measure of exchange-rate movements. Furthermore, he suggests that for the Swedish Bullionist Controversy, the broad money supply $M$ did not matter since banknotes were the dominant means of payment. However, whereas this might be true after the massive increase in banknotes of the 1750s, this was not the case before the 1740s (see Figure 2). For now, the VAR is kept as parsimonious as possible ignoring the effect of the broad money supply. However, introducing the effect of the broad money supply will be taken up as robustness check in Section 5 .

${ }^{14}$ The lack of a formal underpinning manifests itself in the discussion around the quantity theory. According to Eagly (1971, p.20), the Cap economic analysis failed to develop the quantity theory, whereas Niehans (1990, p.58) suggests that the principles of the quantity theory and purchasing power parity can e.g. be found in Christiernin (1761). However, the Caps' position is here thought to merely postulate a positive connection between the amount of banknotes in circulation, inflation and, in turn, the exchange rate without invoking the quantity theory. Furthermore, as mentioned in Section 2.2, the subsidies to the industrial sector were one reason why the Caps were highly sceptical of paper mercantilism. Hence, public debt $B$ could, in principle, be added as explanatory variable for the increase in banknotes, which would yield the causal ordering $B \rightarrow N \rightarrow \pi \rightarrow S$. However, to concur with Officer (2000, 2008), the parsimonious model of (2) will be used as benchmark. Yet, when adding $B$ as additional variable to the Caps' model, the essence of the results did not change.
} 


$$
N \rightarrow \pi \rightarrow S \rightarrow W
$$

Whereas the estimation of a VAR based on a vector $Y_{t}$ of endogenous time series is relatively straightforward, the structural relationship between these variables depends on such things as the Cholesky ordering. To account for the fact that the various camps in the Swedish Bullionist Controversy invoked specific chains of causality, which map into different Cholesky orderings, this paper will deviate from Officer (2000) by considering the three theoretically motivated chains of causality of (1), (2), and (3), rather than confounding economic with Granger causality (see also Hendrickson, 2018a). As in Officer (2000), the structural relationships will be analysed by impulse response functions, which depict how a shock in e.g. the amount of banknotes propagates to other variables of $Y_{t}$, as well as forecast error variance decompositions, which report the proportion of movements of a given variable to its own shock relative to the shocks in the other variables in $Y_{t}$.

\section{Data}

The following annual data have been collected to underpin an empirical assessment of the Swedish Bullionist Controversy. Recall from Section 2 that the controversy focused on the effect of paper money in form of banknotes $(N)$, which reflects the total amount in circulation as recorded in the yearbooks of the Riksens Ständers Bank. The exchange rate $(S)$ refers to the price of the Swedish copper daler per Hamburg reichsthaler banco. This reflects a market exchange rate on Hamburg, on which most Swedish bills of exchange were drawn (Kindleberger, 1982, p.50; Eagly, 1971, p.45). The impact of paper money upon inflation is measured by the percentage change of the price index, denoted by $\pi$, as regards a consumer basket containing mainly foodstuff, but also sources of energy such as wood or coal, textiles, and building materials. As regards the effect of nonmonetary variables, balance-of-payments statistics are unfortunately unavailable for eighteenth-century Sweden. However, at the time, the agricultural sector was still dominant by e.g. accounting for more than half of Swedish employment in 1760 (Heckscher, 1954, p.141). Hence, even more than in Officer's (2000, p.200) empirical investigation of the Bullionist controversy in early industrialised Britain, international trade deficits were probably correlated with a bad state of the harvest and subsequent large imports of agricultural products. Available data on the crop production in Scania, which at the time was "beginning to assume its 
position as granary of Sweden" (Heckscher, 1934, p. 153), could therefore provide a proxy for the quality of the harvest, denoted by $H Q$, and, in turn, balance-of-payments issues. Of course, there is no perfect correlation between Scanian crop production and the overall state of the harvest. Hence, as an alternative, available data on the real price for grain $(P G)$ across the entire Kingdom of Sweden will also be used to reflect the state of the harvest. Substantial capital exports arose, among other things, from foreign military interventions, which were typically associated with an increase in real public debt, denoted by $B$ (see Figure 1 and Jonung, 1976, p.42). Last but not least, recall that P.N. Christiernin also considered the effect of monetary variables - and in particular a monetary contraction resulting in a deflation - on the state of the economy, which is here measured by real wages, as denoted by $W$. Wages reflect payments to unskilled labour in the Stockholm area. Of course, they represent the conditions in the salaried segment of the economy, rather than subsistence farming in peripheral areas. ${ }^{15}$

It is unclear in which year an empirical assessment of the Swedish Bullionist Controversy should start. As mentioned above, the controversy took place when Sweden was on a suspended specie standard between 1745 and 1776. The downside of focusing on this period with inconvertible banknotes is that the corresponding sample is relatively short and covers only 31 years. The Riksens Ständers Bank began to issue transfer notes already in 1701 . However, as shown by Figure 1, during the first decade or so, the demand for these notes was negligible. The amounts of paper money only began to grow from 1710 onwards when copper plates were minted in large quantities, and notes could be used for tax payments after 1726 (Edvinsson and Ögren, 2014, pp.301ff). The policy of paper mercantilism and the financing of the war against Russia between 1741 and 1743 led to a further increase in the amount of banknotes in circulation. Hence, to obtain a long sample, the starting date of 1710 is chosen as it marks the beginning of the spectacular advance of paper money, which accounted for less than 1 per cent of money in 1710, but almost 80 per cent in 1776 (see Figure 2). The disadvantage of estimating a VAR with this long sample is that incongruent currency systems with convertible and inconvertible paper money are covered. ${ }^{16}$

\footnotetext{
${ }^{15}$ In principle, it would be possible to employ real GDP as a broad measure of economic activity. However, the corresponding data published in the Historical Monetary and Financial Statistics of Sweden (2014) have been extrapolated from the current and past quality of the harvest, population, and prices. Hence, the historical GDP series would, by construction, be connected with other variables in the sample and, hence, be rather unsuitable for a VAR analysis.

${ }^{16}$ Officially, between 1681 and 1709, Sweden was on a silver standard and, between 1709 and 1776 , on a copper standard, which was interrupted by fiat currency systems between 1716 and 1719 as well as 1745 and 1776 (see Edvinsson, 2010, pp.43-44.).
} 
Figure 2: Banknotes as a share of the monev sunnlv



Notes: The amount of banknotes $(N)$ is defined in Table 1. The money supply $(M)$ re fers to banknotes and $\infty$ ins in circulation within the King dom of Sweden and has been taken from the Historical Monetary and Financial Statistics of Sweden (2014); Volume II, Swedish money supply 1620-2012; Table A7.1.

The definitions of the data are summarised in Table 1. The main source are two volumes on the Historical Monetary and Financial Statistics of Sweden, where numerous details about the construction of the data can be found. All variables have been transformed into logarithms implying that differences reflect percentage changes. All monetary values are expressed in terms of copper daler (or daler kopparmynt), which was a common unit of account at the time (see e.g. Edvinsson and Ögren, 2014, p.297). Reflecting the multicurrency standard in eighteenth-century Sweden discussed in Section 2.1, some variables needed transforming into copper dalers.

In the bottom panel of Table 1, for the long sample (1710-1776), conventional Augmented Dickey Fuller (ADF) tests reject the presence of unit roots for all variables (the lag length has been determined by the minimum of the Schwarz Information Criterion (SIC)). Aside from inflation and real wages, variables tend to grow. Therefore, the test statistics include a deterministic trend. However, contemplating the short sample (1745-1775) can give rise to contradictory results. Hence, issues associated with potential non-stationary will be important when checking the results of Section 5 for robustness. 


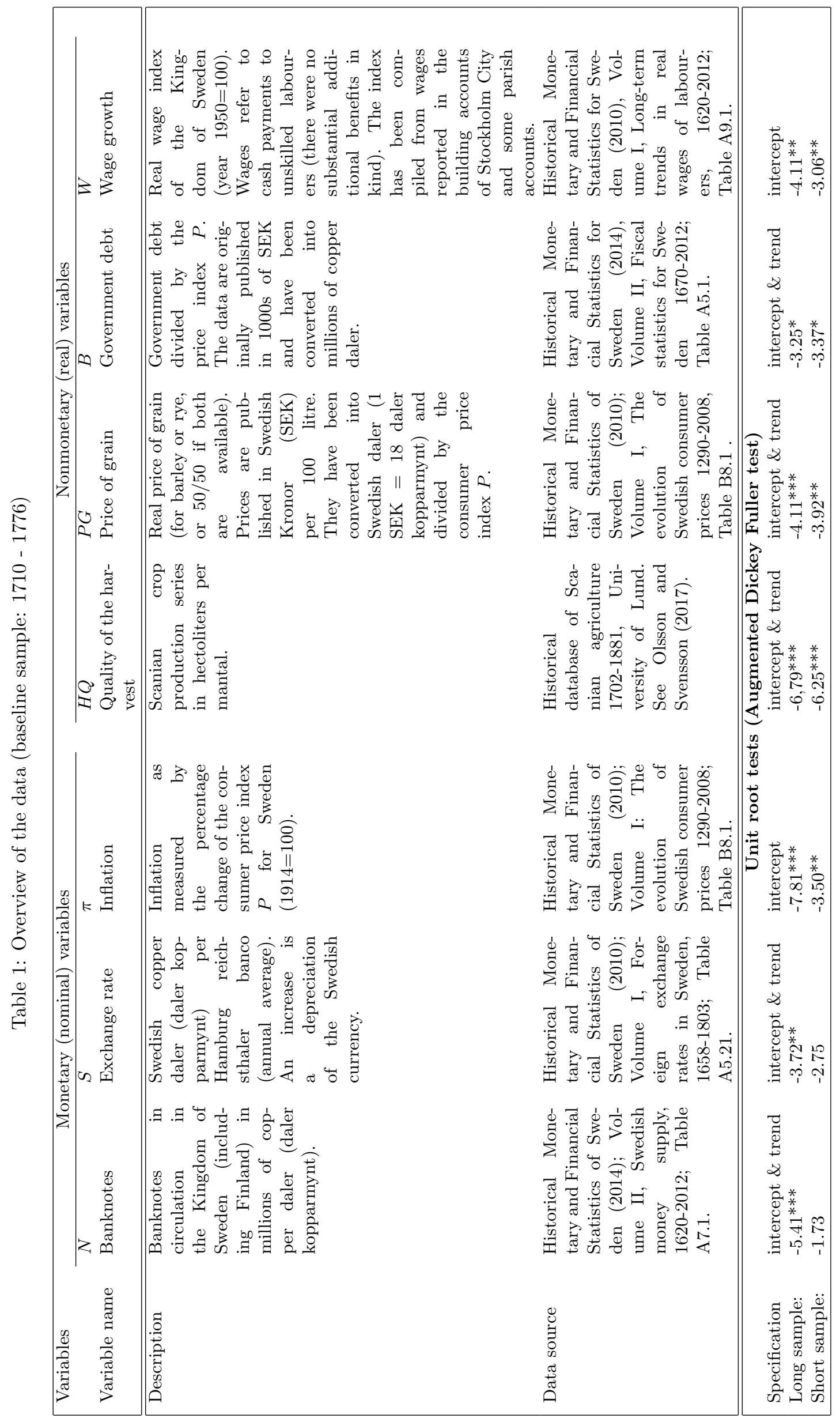




\section{Empirical results}

With stationary variables, a VAR in (logarithmic) levels - including an exogenous constant and trend to account for the growth of some variables - is the appropriate model. When estimating the reduced-form VAR, the minimum of the Schwarz Information Criterion (SIC) determined how many past observations are included. This yields a lag-length of 2 years for the Caps' model and the long sample (1710-1776), and a lag-length of 1 year otherwise. To save space, the coefficient estimates from the reduced-form VARs, which do not lend themselves to a structural interpretation, are not reported here, but are available on request.

\subsection{Impulse response functions}

Across the various VARs, Figure 3 depicts impulse response functions for the impact of a 1 percentage increase of the amount of banknotes $(N)$ upon the exchange rate of the Swedish currency as well as inflation over 20 years. Further to the discussion of Section 3 about the appropriate Cholesky ordering, three version of the recursive VAR have been estimated. In particular, the top panel reports the results of the Caps' model e.g. $N \rightarrow \pi \rightarrow S$, the middle panel the Hats' model e.g. $H Q \rightarrow B \rightarrow S \rightarrow \pi \rightarrow N$, and the bottom panel Christiernin's model e.g. $N \rightarrow \pi \rightarrow S \rightarrow W$. Furthermore, columns 1 and 2 refer to the long sample (1710-1776), and columns 3 and 4 to the short sample (1745-1776). Since all variables have been transformed into logarithms, the responses reported by the solid lines reflect percentage changes. Furthermore, the shaded areas delimit the 95 per cent confidence interval calculated from analytic (asymptotic) standard deviations.

Consistent with the view of the Caps, a significant upsurge of the price for foreign currency, which reflects a depreciation, as well as a by and large significant increase in inflation seem to have been caused by an expansion of the banknote supply. Across all Cholesky orderings, both the depreciation as well as the inflationary impact are temporary in the sense of vanishing after around 10 years. The maximum impact upon inflation occurs after around 2 years, whereas the maximum impact upon the exchange rate occurs after around 5 years. Furthermore, the standard deviations are larger, and the increase in inflation smaller for the short sample when compared with the long sample. Unsurprisingly, the effect of banknotes in circulation tends to be larger for the Caps' model, which theoretically attributes the high prices of goods and foreign currency to monetary variables. What is more remarkable, although focusing on nonmonetary variables, even the Hats' model gives 
Figure 3: Response of the exchange rate $(S)$ and inflation $(\pi)$ to an impulse in the amount of banknotes in circulation $(N)$

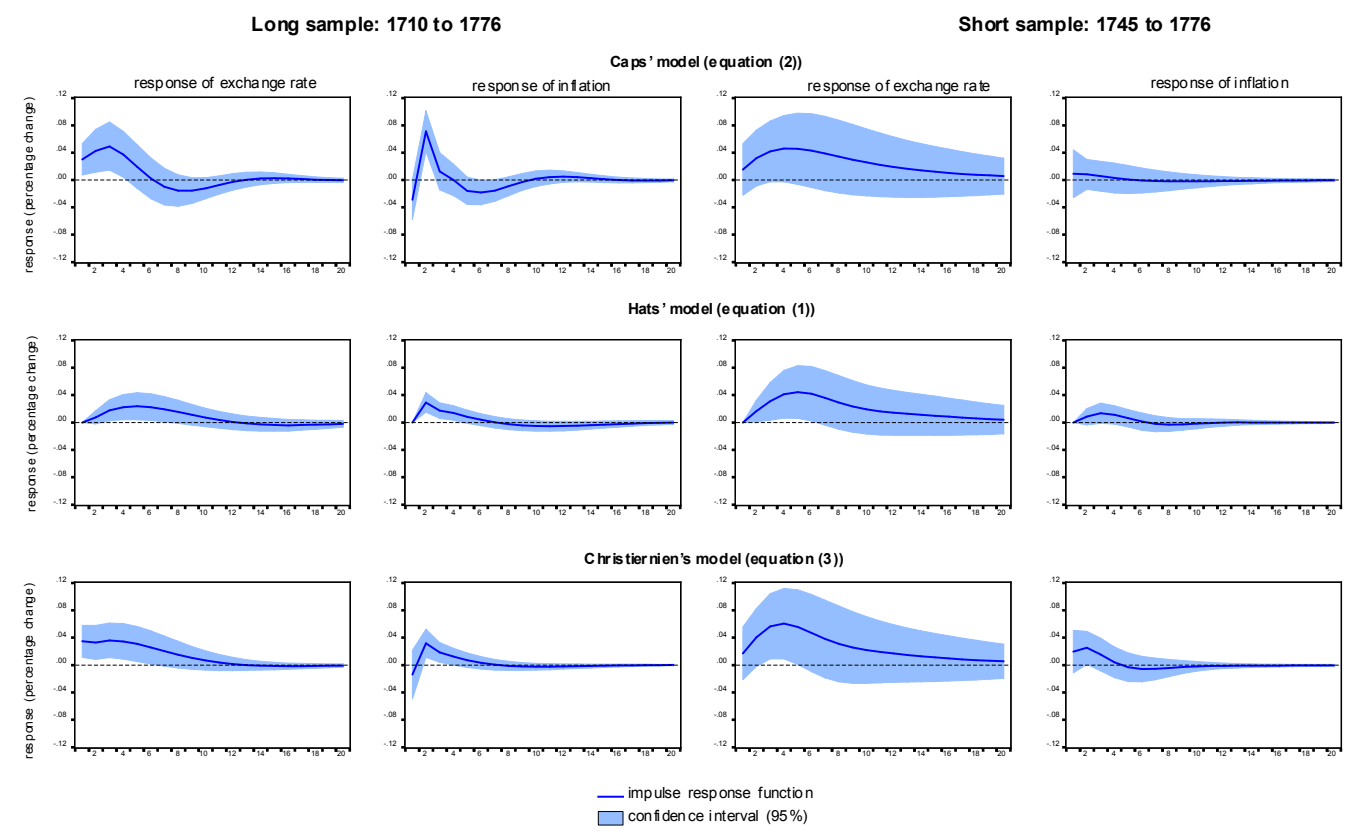

rise to a significant empirical link between banknotes and the average price for goods and foreign currency. The results of Figure 3 stand in sharp contrast to Officer (2000), who found only scant empirical support for the bullionist position with British data around the year 1800 .

Figure 4 depicts the responses of the exchange rate and inflation to impulses in nonmonetary variables, including real public debt $(B)$ and the quality of the harvest $(H Q)$. Recall from the discussion above that these variables were ignored by the Caps and dismissed as largely irrelevant by P.N. Christiernin. Hence, their models are not suited to calculate impulse response functions in Figure 4. Conversely, according to the Hats' position (e.g. equation (1)), balance-of-payments issues caused by large imports of agricultural products after a bad harvest or capital exports to fund foreign military interventions (which manifest themselves in an upsurge of public debt), should have been the main causes for the high price for foreign currency and goods. The results of Figure 4 lend only scant support to this view. In particular, according to the top panel, an increase in public debt $B$ does not significantly increase the exchange rate and inflation, which stands in contrast to the hypothesis that the Swedish currency was weakened, since government deficits were partly financed through foreign capital. Turning to the role of agricultural imports and the quality of the harvest, 
recall that the corresponding effects are hard to measure due to the absence of comprehensive international trade statistics. Still, in the middle panel, there is some evidence that a large crop production during a given year did indeed significantly lower inflation. However, this effect lasts only for one year. Conversely, the corresponding decrease of the price for foreign exchange, reflecting an appreciation of the Swedish currency, is small and not significant. When approximating the quality of the harvest through the real price of grain, the results are different. In particular, as reported in the bottom panel, there is evidence that an increase in the price of grain, which could signal a bad harvest, results in a subsequent increase of the price of foreign currency (e.g. a depreciation) as well as the price level in general (e.g. inflation). This would be consistent with the view that a trade deficit, caused by large imports of agricultural products after a bad harvest, can undermine the value of a currency.

Figure 4: Response of the exchange rate $(S)$ and inflation $(\pi)$ to an impulse in public debt $(B)$, the quality of the harvest $(H Q)$, and the price of $\operatorname{grain}(P G)$

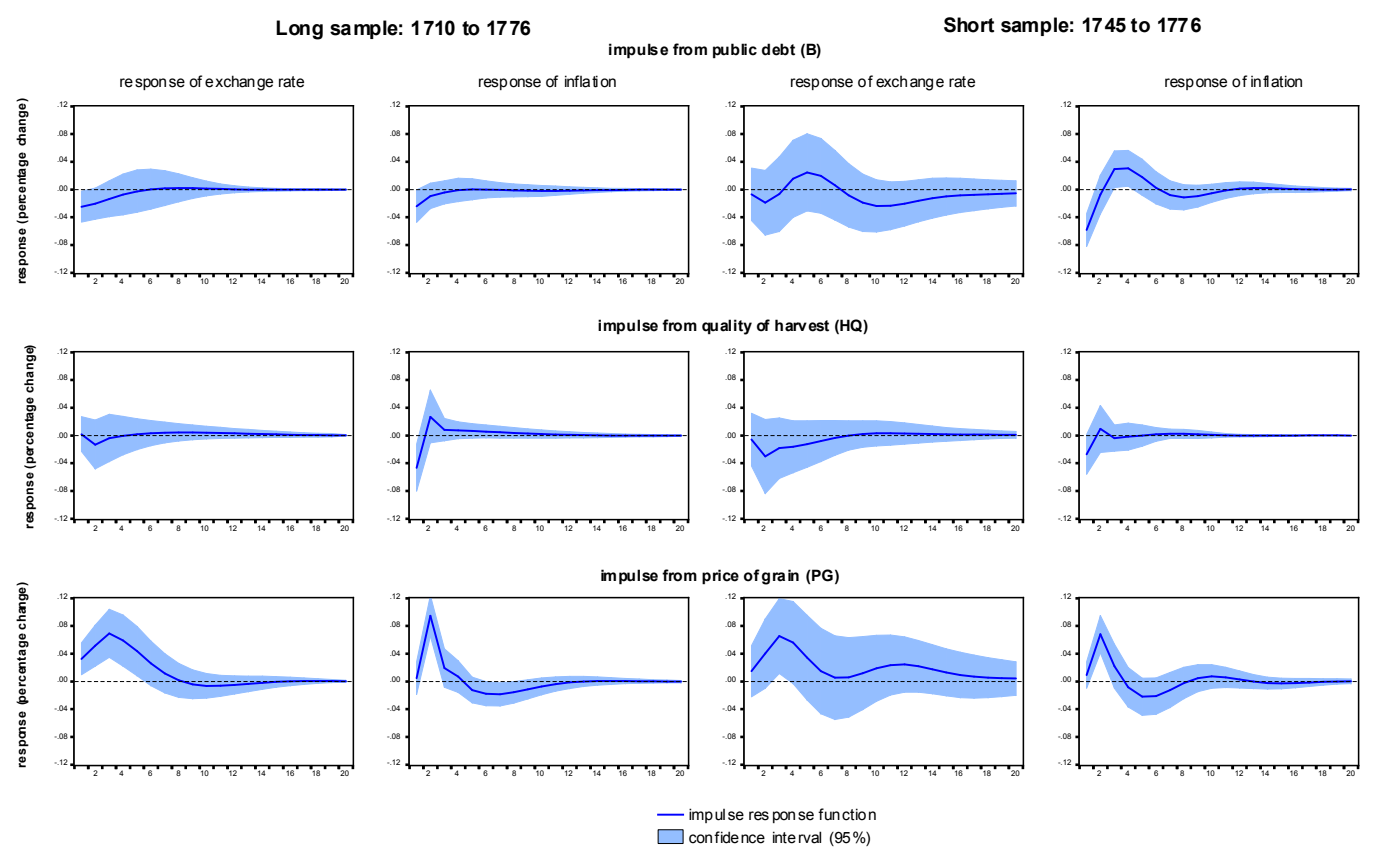

As alluded to at the outset, the empirical literature on the British Bullionist Controversy has been plagued by vagaries as regards the stationarity or non-stationarity of the data, the structural identification of the VAR, and the appropriate time period covered by the data. To deal with similar issues within the present context, the results of Figures 3 and 4 have been subject to a large number of robustness checks. In particular, the data presented 
in Table 1 contain variables in logarithmic levels. Similar to the specification of Officer (2000), the reduced-form VARs have been re-estimated with all variables transformed into logarithmic differences. Another way to deal with potential non-stationarity is to test for cointegration. Across the three models encapsulated in equations (1) to (3), and depending on the specification of the test statistic as regards the inclusion of trends and intercepts as well as the length of the sample, standard Johansen tests consistently uncovered at least one cointegrating relationship. If the variables are non-stationary (a big if given the test statistics of Table 1), but they are cointegrated, a vector error correction model (VECM) would be appropriate. Furthermore, in terms of choosing the starting date of the sample, there is a trade-off between including more observations, and having to control for breaks in the currency, economic, or political regime. However, reflecting the discussion of Section 3, the reduced-form VARs underpinning Figures 3 and 4 have been re-estimated with samples starting as far back as the years 1688, 1702, and 1720. Finally, the effect of banknotes could have occurred via the money supply $M$, which encompasses all means of payments. To distinguish, for example, between a scenario where an increase of banknotes was associated with an increase in the money supply, or merely a replacement of coins, $M$ could be inserted after $N$ in the three chains of causality introduced above. Across all these modifications, the exact magnitude, the adjustment speed, as well as the standard deviations of the impulse response functions reported in Figures 3 and 4 did change to some degree. Conversely, the general pattern remained intact in the sense that the amount of banknotes almost always resulted in a significant depreciation of the Swedish currency as well as an upsurge in inflation, whereas the impact from nonmonetary variables was mixed. For the sake of brevity, all these permutations of the baseline results are not reported here, but are of course available on request. ${ }^{17}$

\section{$5.2 \quad$ Forecast error variance decomposition}

Whether the amount of banknotes in circulation was an exogenous cause, or an endogenous consequence to changes in economic conditions, was a key issue in bullionist controversies.

\footnotetext{
${ }^{17}$ A caveat against impulse response functions derived from a VAR is that they depend on the specification of the statistical model as well as the identifying assumptions. To make the results more robust to misspecification of the multivariate time-series model, Jorda (2005) suggests to estimate impulse response functions from local projections, that is a collections of direct forecasting models re-estimated for each forecast horizon. However, with the relatively small number of observations available within the current context, the standard deviations of the impulse response functions estimated via the local-projections method were relatively large (especially for longer time horizons). Hence, the result that the increase in inflation and the depreciation of the currency during the Swedish Bullionist Controversy was significantly caused by an overissuing of banknotes depends, to a substantial degree, on the assumption that the underlying VARs are correctly specified.
} 
To resolve this issue, Table 2 reports the results of forecast error variance decompositions of the amount of banknotes in circulation to shocks in monetary and nonmonetary variables, and also contemplates the opposite scenario in terms of a decomposition of these variables to shocks in banknotes in circulation. Again, a distinction is made between the long sample (1710-1776) and the short sample (1745-1776). In particular, for each sample, the top panel looks at the variance decomposition of banknotes $(N)$ to shocks in the quality of the harvest $(H Q)$, government debt $(B)$, inflation $(\pi)$, the exchange rate $(S)$, and finally banknotes themselves. The bottom panel reverses the scenario by looking at the variance decomposition of these monetary and nonmonetary variables to shocks in banknotes. Similar to the calculation of the impulse response function, the variance decomposition depends on the adopted Cholesky ordering. Hence, the first columns employ the model of the Hats for identification. In reference to equation (1), this is obviously a scenario where shocks in variables such as government debt $(B)$ and the quality of the harvest $(H Q)$ matter. The remaining columns employ the model of the Caps for identification. In reference to equation (2), this is obviously a scenario where only shocks in banknotes $(N)$, inflation $(\pi)$, and the exchange rate $(S)$ matter (the results of P.N. Christiernien's model of equation (3) were almost identical to the Caps' model and are, hence, not separately reported).

By and large, the variance decompositions of Table 2 seem to lend more support to the bullionist than the anti-bullionist point of view. Above all, the development of banknotes in circulation is mainly driven by its own shock. For a horizon of less than 5 years and the Caps' model, the corresponding fraction is well over 80 per cent. Even for the Hats' model and a horizon of more than 5 years, around half of the forecast error variance of $N$ can be attributed to its own shock. Furthermore, as regards the effect of shocks in the non-banknote variables reported in the top panels, government debt is important in terms of accounting for around 20 per cent of the variation in banknotes during a forecast horizon of more than 10 years. Although this result lends some support to the anti-bullionist point of view, in the sense that nonmonetary variables had at least a partial impact upon the supply of paper money, it can also be reconciled with the bullionist position, if the government was monetising its debt (see footnote 14). Arguably, it was indeed the case that the Riksens Ständers Bank provided a key source for funding wars as well as early industrial projects (see e.g. Hendrickson, 2018b). Finally, whether shocks in inflation or the exchange rate matter for the amount of banknotes in circulation depends on the sample, the Cholesky ordering, 
Table 2: Variance decompositions as regards the amount of banknotes in circulation

\begin{tabular}{|c|c|c|c|c|c|c|c|c|}
\hline \multicolumn{9}{|c|}{ Long Sample: 1710-1776 } \\
\hline \multirow{4}{*}{$\begin{array}{l}\text { Variance decomposition of... } \\
\text {...to shock in: } \\
\text { Model for identification: } \\
\text { Horizon (years) }\end{array}$} & \multicolumn{8}{|c|}{ Banknotes in circulation $(N)$} \\
\hline & $H Q$ & $B$ & $\mathrm{~S}$ & $\pi$ & $\mathrm{N}$ & $\mathrm{N}$ & $\pi$ & $\mathrm{S}$ \\
\hline & \multicolumn{5}{|c|}{ Hats } & \multicolumn{3}{|c|}{ Caps } \\
\hline & & & & & & & & \\
\hline 1 & 1.3 & 21.3 & 2.8 & 9.8 & 64.7 & 100 & 0 & 0 \\
\hline 2 & 1.0 & 23.2 & 1.9 & 7.2 & 66.8 & 91.9 & 3.2 & 4.9 \\
\hline 3 & 1.4 & 22.3 & 2.8 & 7.0 & 66.5 & 87.7 & 4.2 & 8.1 \\
\hline 5 & 1.9 & 20.0 & 8.0 & 7.4 & 62.7 & 81.6 & 4.3 & 14.2 \\
\hline 10 & 2.1 & 17.6 & 17.2 & 7.7 & 55.3 & 78 & 4.9 & 17.0 \\
\hline$\infty$ & 2.1 & 17.8 & 18.1 & 7.6 & 55.3 & 78 & 4.9 & 17.0 \\
\hline \multirow{4}{*}{$\begin{array}{l}\text { Variance decomposition of... } \\
\text {...to shock in: } \\
\text { Model for identification: } \\
\text { Horizon (years) }\end{array}$} & $H Q$ & $B$ & $\mathrm{~S}$ & $\pi$ & $\mathrm{N}$ & $\mathrm{N}$ & $\pi$ & $\mathrm{S}$ \\
\hline & \multicolumn{8}{|c|}{ Banknotes in circulation $(N)$} \\
\hline & \multicolumn{5}{|c|}{ Hats } & \multicolumn{3}{|c|}{ Caps } \\
\hline & & & & & & & & \\
\hline 1 & 0 & 0 & 0 & 0 & 64.7 & 100 & 5.5 & 9.6 \\
\hline 2 & 0.1 & 0 & 0.1 & 2.5 & 66.8 & 91.9 & 28.0 & 13.6 \\
\hline 3 & 0.1 & 0.1 & 0.8 & 3.6 & 66.5 & 87.7 & 26.2 & 18.1 \\
\hline 5 & 0.2 & 0.1 & 2.5 & 4.3 & 62.7 & 81.6 & 25.4 & 20.2 \\
\hline 10 & 0.2 & 0.6 & 4.6 & 4.2 & 55.3 & 78 & 26.3 & 21.5 \\
\hline$\infty$ & 0.2 & 1.5 & 4.7 & 4.2 & 55.3 & 78 & 26.4 & 21.6 \\
\hline
\end{tabular}

\begin{tabular}{|c|c|c|c|c|c|c|c|c|}
\hline \multicolumn{9}{|c|}{ Short Sample: 1745-1776 } \\
\hline \multirow{3}{*}{$\begin{array}{l}\text { Variance decomposition of... } \\
\text {...to shock in: } \\
\text { Model for identification: } \\
\text { Horizon (years) }\end{array}$} & \multicolumn{8}{|c|}{ Banknotes in circulation $(N)$} \\
\hline & \multicolumn{5}{|c|}{ Hats } & \multicolumn{3}{|c|}{ Caps } \\
\hline & & & & & & & & \\
\hline 1 & 4.3 & 1.7 & 6.9 & 21.1 & 66.0 & 100 & 0 & 0 \\
\hline 2 & 3.5 & 4.0 & 4.3 & 27.1 & 61.0 & 95.3 & 3.3 & 1.3 \\
\hline 3 & 2.5 & 7.7 & 2.8 & 30.6 & 56.4 & 91.8 & 4.2 & 3.9 \\
\hline 5 & 1.6 & 10.6 & 2.6 & 32.5 & 52.7 & 87.0 & 2.8 & 9.8 \\
\hline 10 & 1.2 & 15.1 & 5.0 & 30.0 & 48.6 & 79.9 & 3.4 & 16.7 \\
\hline$\infty$ & 1.2 & 17.8 & 5.6 & 29.0 & 46.4 & 77.7 & 4.1 & 18.2 \\
\hline \multirow{4}{*}{$\begin{array}{l}\text { Variance decomposition of... } \\
\text {...to shock in: } \\
\text { Model for identification: } \\
\text { Horizon (years) }\end{array}$} & $H Q$ & $B$ & & $\pi$ & $\mathrm{N}$ & $\mathrm{N}$ & $\pi$ & $\mathrm{S}$ \\
\hline & \multicolumn{8}{|c|}{ Banknotes in circulation $(N)$} \\
\hline & \multicolumn{5}{|c|}{ Hats } & \multicolumn{3}{|c|}{ Caps } \\
\hline & & & & & & & & \\
\hline 1 & 0 & 0 & 0 & 0 & 66.0 & 100 & 0.8 & 2.0 \\
\hline 2 & 0.4 & 0 & 0.8 & 1.2 & 61.0 & 95.3 & 1.2 & 5.3 \\
\hline 3 & 0.5 & 0.1 & 2.4 & 4.0 & 56.4 & 91.8 & 1.5 & 9.1 \\
\hline 5 & 0.7 & 1.0 & 3.3 & 12.0 & 52.7 & 87.0 & 1.5 & 16.9 \\
\hline 10 & 2.1 & 2.1 & 3.3 & 19.4 & 48.6 & 79.9 & 1.6 & 25.8 \\
\hline$\infty$ & 2.4 & 2.2 & 3.3 & 20.0 & 46.4 & 77.7 & 1.7 & 27.6 \\
\hline
\end{tabular}

Notes: The proportion of the forecast error variance accounted for by a typical shock is measured in per cent. A typical shock is a change of one standard deviation (which is a 1 per cent change with for the current variables, which have been transformed into logarithms). The models of the Hats and the Caps to reach structural identification are described around equations (1) and (2), respectively. For the variance decomposition of $N$, rows may not sum to 100 , due to rounding. 
and the time horizon.

In the bottom panels, the role of shocks in banknotes upon other variables depends crucially on the underlying Cholesky ordering and the sample. With the short sample, and especially with the Caps' model, changes in the supply of paper money exhibit considerable effects on nominal variables such as inflation and the exchange rate of the Swedish currency. However, the corresponding values of the variance decomposition with the Hats' model and the long sample are much smaller.

Given the results of the variance decomposition, the position of the Caps as Swedish Bullionists seems to be more coherent. The amount of banknotes in circulation is largely exogenous and is not a mere reaction to balance-of-payments issues or inflation. Furthermore, adopting a model with largely exogenous banknotes gives indeed rise to considerable knock-on effects on prices and the exchange rate. Conversely, the anti-bullionist position of the Hats, according to which the upsurge in banknotes was primarily a consequence of nonmonetary economic developments, finds mixed support at best.

\section{Summary and conclusion}

Bullionist controversies are a strong testimony to how important monetary issues, such as the link between money, inflation, exchange rate movements, and employment, have been debated at a surprisingly advanced level long before monetary economics became a specialised, and highly formalised, academic discipline. This paper has provided an empirical assessment of the Swedish case, which involves a historical debate on whether inconvertible banknotes were responsible for the upsurge in inflation and the outstanding depreciation of the Swedish currency around the year 1760. By combining modern time-series techniques with historical data, it is possible to shed more light into this Swedish version of a bullionist controversy. In particular, the results of an empirical assessment with structural vector autoregression techniques suggest that the increase in paper money, at the time in form of banknotes that were no longer convertible into precious metals, caused indeed a significant upsurge in inflation and a depreciation of the exchange rate. Conversely, it is less clear whether nonmonetary factors, such as balance-of-payment deficits, played a major role for these developments. Despite the absence of such things as a global financial system, collective wage bargaining, or routine fiscal and monetary policy interventions to stabilise 
the macroeconomy, the results uncover links between money, inflation, and the exchange rate, that are, at least qualitatively, similar to those typically found in the modern world. Furthermore, the findings are also broadly in line with the most recent empirical work on the more famous British Bullionist Controversy. 


\section{References}

Bernholz, P. (2003), Monetary Regimes and Inflation - History, Economic and Political Relationships, Edward Elgar, Cheltenham.

Eagly, R.V. (1963), Money Employment and Prices: A Swedish View: 1761, The Quarterly Journal of Economics 77, 626-636.

Eagly, R.V. (1969), Monetary Policy and Politics in Mid-Eighteenth Century Sweden, The Journal of Economic History 29, 739-757.

Eagly, R.V. (1971), The Swedish Bullionist Controversy: P.N. Christiernin's Lectures on the High Price of Foreign Exchange in Sweden (1761), The American Philosophical Society, Philadelphia.

Edvinsson, R. (2010), Swedish monetary standards in a historical perspective, in R. Edvinsson et al. (eds.), Historical Monetary and Financial Statistics for Sweden, Volume I: Exchange rates, prices, and wages, 1277-2008, Ekerlids Förlag, Stockholm.

Edvinsson, R. (2012a), Early modern copper money: multiple currencies and trimetallism in Sweden 1624-1776, European Review of Economic History 16, 408-429.

Edvinsson, R. (2012b), The international political economy of early modern copper mercantilism: Rent seeking and copper money in Sweden 1624-1776, Explorations in Economic History 49, 303-315.

Edvinsson, R., and Ögren (2014), A. Swedish money supply, 1620-2012, in R. Edvinsson et al. (eds.), Historical Monetary and Financial Statistics for Sweden, Volume II: House Prices, Stock Returns, National Accounts, and the Riksbank Balance Sheet, 1620-2012, Ekerlids Förlag, Stockholm.

Enders, W. (2014), Applied Econometric Time Series, Wiley Series in Probability and Statistics, Hoboken (NJ) (4th ed.).

Fregert, K., and Gustafsson, R. (2014), Fiscal statistics for Sweden, 1670-2011, in R. Edvinsson, Rodney et al. (eds.), Historical Monetary and Financial Statistics for Sweden, Volume 
II: House Prices, Stock Returns, National Accounts, and the Riksbank Balance Sheet, 16202012, Ekerlids Förlag, Stockholm.

Geweke, J. (1984), Inference and causality in economic time series models, in Z. Griliches and M.D. Intriligator (eds.), Handbook of Econometrics Vol II, North Holland, Amsterdam.

Heckscher, E.F. (1954), An Economic History of Sweden, Harvard University Press, Cambridge (Mass.)

Heckscher, E. (1955), Mercantilism, Volume 2, George Allen and Unwin, London.

Hendrickson, J.R. (2018a), The Bullionist Controversy: Theory and New Evidence, Journal of Money Credit and Banking 50, 203-241.

Hendrickson, J.R. (2018b), The Riksbank, Emergency Finance, Policy Experimentation, and Sweden's Reversal of Fortune, University of Mississippi Working Paper.

Jonung, L. (1976), Money and prices in Sweden, 1732-1972, Scandinavian Journal of Economics 78, 40-58.

Jorda, O. (2005, estimation and Inference of Impulse Responses by Local Projections, The American Economic Review 95, 161-182.

Kindleberger, C. (1984), A Financial History of Western Europe, Routledge, London and New York.

Lütkepohl, H. (2010), New Introduction to Multiple Time Series Analysis, Springer, Berlin.

Myhrman, J. (1976), Experiences of flexible exchange rates in earlier periods: theories, evidence, and a new view, Scandinavian Journal of Economics 76, 169-196.

Nachane, D.M., and N.R. Hatekar (1995), The Bullionist Controversy: An Empirical Reappraisal, The Manchester School 63, 412-425.

Niehans, J. (1990), A History of Economic Theory: Classic Contributions, 1720-1980, The Johns Hopkins University Press, Baltimore.

Officer, L.H. (2000), The Bullionist Controversy: A Time-series analysis, International Journal of Finance and Economics 5, 197-209. 
Officer, L.H. (2008), Bullionist Controversies (empirical evidence), in S.N. Durlauf, and L.E. Blume (eds.), The New Palgrave Dictionary of Economics, Palgrave Macmillan, New York.

Olsson, M. and P. Svensson (2017), Estimating agricultural production in Scania, 17021881. User guide for the Historical Database of Scanian Agriculture and overall results, Lund Papers in Economic History.

Redish, A. (2000), Bimetallism: An Economic and Historical Analysis, Cambridge University Press, Cambridge.

Roberts, M. (1986), The Age of Liberty, Cambridge University Press, Cambridge.

Tobin, J. (1970), Money and income: Post hoc ergo propter hoc? Quarterly Journal of Economics 84, 310-317.

Viner, J. (1937), Studies in the Theory of International Trade, Harper and Brothers Publishers, New York. 